\title{
Motivation in the Perspective of Self Determination Theory (SDT) between Work Environment and Job Satisfaction in Banking Sector
}

\author{
Syed Talib Hussain ${ }^{1}$, Shen Lei ${ }^{1}$, Zainul Abideen ${ }^{2} \&$ Syed Hadi Hussain ${ }^{3}$ \\ ${ }^{1}$ Glorious Sun School of Busniess and Mangement, Donghua University, Shanghai, China \\ ${ }^{2}$ Mohammad Ali Jinnah University, Islamabad, Pakistan \\ ${ }^{3}$ Institute of Management Studies, University of Peshawar, Peshawar, Pakistan \\ Correspondence: Syed Talib Hussain, Glorious Sun School of Business and Management, Donghua University \\ West Yan'an Road, 1882, Shanghai 200051, China. Tel: 86-150-0171-5310. E-mail: talib_14@yahoo.com
}

Received: July 27, 2015

Accepted: August 11, 2015

Online Published: October 26, 2015

doi:10.5539/ibr.v8n11p39

URL: http://dx.doi.org/10.5539/ibr.v8n11p39

\begin{abstract}
The expansion of business, fulfillments of demands and profits maximization have created stress and less motivation for job satisfaction. To fulfill the demand of organizations and maximize the satisfaction level of employees; the extrinsic and intrinsic motivation beyond psychological motivation has been used in this study to minimize stress level and maximize the satisfaction level among employees. This study explains work stress, job overload; performance pressure and job satisfaction while in motivation; the extrinsic/intrinsic factors of Self Determination Theory (SDT) have been used. Structured questionnaires were used to collect the data. The total distribution was 120 and response rate was 75 percent. The results found that work stress, job overload and performance pressure has negative impact on job satisfaction and employees do not like stress caused by work overload or job overload, while motivation factor has played an important psychological role in the study.
\end{abstract}

Keywords: work stress, job overload, performance pressure, job satisfaction, intrinsic, extrinsic motivation, self-determination theory

\section{Introduction}

The volume of banks in worldwide has increased the progressive and competitive changes in commercial banks. In Pakistan the banking system has been expanded nationwide continuously. On the same time the globalization and privatization changed the service sector of financial institutions in Pakistan. The policies of globalization and privatization compelled and reformed the home banking sector. The drastic policy changes the structural and fiscal deficit in the country. The globalization and liberalization, the entrance of new banks in the sector, downsizing and innovation of new technologies have created high level of stress among employees.

According to the study of Fields (2002) that work environment explains work stress, role conflict, role ambiguity, job overload, lack of control, job performances and responsibilities pressure and conflict between work and non-work responsibilities. Sveinsdottir, Biering, and Ramel (2005) state that "Work environment" and the "Organization of environment" applies to both general organizational and managerial characteristics, and these are applying to individual workers and vary in different professions.

In the study of Altaf and Awan (2011) that job overload explains two perceptions of employees; quantitative job overload and qualitative job overload. The quantitative job overload explains the working hours, lesser holidays and pressure for overtime and so on; while qualitative job overload explains the ease of accomplishing the given target (Kahn, 1980). Heavy work load and long working hours lead individuals to the degree of anxiety and stress; which causes performance pressure, work stress, work load, physical and mental issues. Rapid changes in global, enhance production level, and competition have created performance pressure which influences job stress and job satisfaction (Cascio, 1995). In the study of Townley (2000) that employees were unhappy in work extended hours and large workload's culture. The work itself is not concern or a problem; rather than job overload on an individual or employee which exceeds the normal limits for human; is always a concern to the employee as well as for the employer. The focus should be on stress prevention neither stress intervention for tackling of organizational problems or issues as well as for individuals in organization. For this purpose more studies have to be brought into consideration and new tools for evaluation of intensity of individual distress 
(McVicar, 2003). Therefore different training sessions and programs have been used, other factors added, job specification and to reorganize the structure and responsibilities, clear role etc. to reduce stress level and increase satisfaction level. But one factor which is known motivation on work environment is used to reduce stress level and increase job satisfaction level. For motivation of employees; the continuously appreciation programs and constant appraisal programs should be given in organization. The motivated employees due to motivation will experience happiness and their contribution to work will increase output (Ahsan et al., 2009). Haqqer et al. (2002) further added Self Determination Theory (SDT) as motivation in contrast as psychological satisfaction for employee's intentions to general motives; caused by workers psychological need for self-determination. According to the study of Sheldon et al. (2004) that Self Determination Theory (SDT) is motivational theory based on the study of (Deci \& Ryan, 1985) psychological needs, self-determined behavioral regulations continuum, explaining extrinsic, intrinsic and amotivtion dimensions.

This study explores whether or not intensity or frequency of stress had a greater impact on job satisfaction. By examining the issues, we hoped to contribute to the body of knowledge about the relationship between stress and job satisfaction by using the Self Determination Theory (SDT) of motivation. Doing so has practical relevance for designing and implementing strategies and interventions to combat stress and increase job satisfaction among banking sectors.

\section{Literature Review}

\subsection{Work Stress and Job Satisfaction}

The study of Newbury and Kamali (2001) states that excess of stress level may increase the employees' dissatisfaction. Elangovan (2001) states that; there is a strong relationship between work stress and job satisfaction. The employees who have work stress they tend to be less satisfied with their jobs (Bennett et al., 2001). According to the study of Lum et al. (1998) that job satisfaction is rationalized following work stress and professional commitment. In the study of Yun lu, Chih Chang, and Lan Wu (2007) that work stress has a direct negative relationship with job satisfaction. The study of Healy and McKay (2000) describes that work stress has negative effect on job satisfaction. Many researchers have found consistently that work stress and job satisfaction has negative relationship (Jina, Lall, McLaughlin, \& Johnson, 1996). In the study of Blegen (1993) that, strong relationship was found between job stress and job satisfaction. Burnout resulted lower degree of job satisfaction and this explains the relationship negatively (Nirel et al., 2008) and job overload causes burnout at job, so low level of job satisfaction is the cause of work overload. Stamps and Piedmonte (1986) states that Job satisfaction and job stress has significant relationship. The work load and working conditions were identified as negatively to the job satisfaction (Vinokur-Kaplan, 1991). The organizations with lack of satisfaction (Ben Fletcher \& Payne, 1980) might be the cause of stress; while the organization having high satisfaction can ease the effect of stress. So in this context the job satisfaction and job stress are interrelated. Landsbergis (1988) described that, employees with high level of work stress associates low level of job satisfaction. Cummins (1990) states that for job dissatisfaction, the job stressors are the predictive and this is a greater predisposition to leave the organization. On the basis of above literature the following hypothesis can be developed.

H1: High level of work stress associates at work will be predictive of low level of job satisfaction.

\subsection{Job Overload and Job Satisfaction}

Job overload is characterized in working hours, lesser holidays, pressure to work overtime, unreasonable work overload and the improbable expectations. According to the study of Qureshi et al. (2012) that stress is the cause of workload and workload leads to lower job satisfaction. Job overload may be physical or psychological, internal or external. In the study of Aryee et al. (2005) that an employee who perceives job overload may experience the fatigue and exhaustion and this could negatively affect the motivation level of satisfaction. In the study of Baltes et al. (1999) that impact of flexi time and job satisfaction was observed as positive and the (Grover \& Crooker, 1995) flexi time causes job satisfaction. The warning symptoms of job overload include sleeping problems, difficulties on concentration, headaches, upset stomach, short irritability or temper and low job satisfaction (Dormann \& Zapf, 2002) the person who has high level of job stress will appear these kind of symptoms. If these symptoms develop in more serious condition; it will appear in psychological (depression, etc.), physical (Headaches, etc.), behavioral (sleeping, violence etc.) and even organizational (absenteeism, reduced productivity etc.) issues (Ettner \& Grzywacz, 2001). The high level of job overload causes problems of emotions (emotional problems) and this leads lover level of job satisfaction (Nirel et al., 2008). Beehr and Bahagat (1985) explore that employees may face ambiguity for completion a work while having a high level of work overload. So this ambiguity will definitely bring worries and nervousness in the employees mind which will minimize the level of work satisfaction, this state of confusion will cause the irritation and apprehension in 
employees jobs and some factors have to be adapted for work and some have to be ignored characteristics of life or job which may be the major chances of frustration (Spector \& Jex, 1998) and this will bring job dissatisfaction. The following hypothesis has been developed on the basis of literature review.

H2: High level of job overload associates at work will be predictive of the lower level of job satisfaction.

\subsection{Performance Pressure and Job Satisfaction}

In the study of Gardner and Cummings (1988) that job satisfaction and job performance are supposed to be decline in regarding with the work overload or job under load while experiencing the job performance. In the study of Hackman and Ollham (1976) that the model of job characteristics grip or embrace the variety of skills and the use of highly developed and sophisticated skill will increase the job interest intrinsically. This study was supported by the study of O'Brien (1983) that the variety of skills and utilizing skills were linked to higher or greater job interest and higher job satisfaction. Absenteeism, lowest turnover and increased output is also linked to one's job satisfaction (Hackman \& Oldham, 1975). According to the study of Argyle (1989) that productivity and job satisfaction has positive and significant relationship. According to the study of Kawakami, Kobayashi, takao, and Tsutsumi (2005) that work overload and continue working hours are the main reasons of distress for workers or employees. Jex and Beehr (1991) states that in working environment of employees the factors of stressors lead to the negative consequences, in term of physiological, physical and behavioral changes, which minimizes the level of job satisfaction among employees. In the study of Nordqvist, Hovmark, and Viktorsson (2004) that the project team members with a higher level of time pressure had lower job satisfaction.

H3: High level of performance pressure is an indicator of lower level of job satisfaction in the several complex antecedent configurations for lower job satisfaction.

Self Determination Theory (SDT) and Motivation as a moderator

The Self Determination Theory focuses on the "Nature" of motivation. This theory states the "Why of behavior". The fundamental assumption is that "Human beings are active, growth oriented organisms; who are naturally inclined toward integration of their psychic elements into a unified sense of self and integration of themselves into larger social structure" (Deci \& Ryan, 2002). The Self Determination Theory is a macro (Cognitive evaluation theory, 1975; Organismic integration theory, 1985; Causality orientation theory, 1985; Basic psychological need theory, 1995) human motivation and personality theory; that explains people spontaneous sentiments, tendencies and innate psychological needs. The Self Determination Theory of Deci and Ryan (2000) explains multidimensional approaches to the motivation and identifies different natures of intrinsic/extrinsic motivation to individuals. The intrinsic motivation named as "Autonomous action" by DeCharms (1968) and Basset and Lloyd (2005) named as "Hawthorn" which means the internal motivation of employees for their social and monetary benefits. So the intrinsic motivation states the activity for its own sake for inherent, interest and satisfaction. The extrinsic motivation named as "Controlled actions" by DeCharms (1968) and named as "Taylorism" by Basset and Lloyd (2005) which explains that basically people are work shy and lazy, so these groups of employees can be provoked by peripheral or external motivation and encouragement. Alders (ERG Theory); Adams (Social Equity Theory); Maslow (Need Theory); Vroom (Expectancy Theory); Skinner (Reward Theory); Herzberq (Two Factor Theory); Taylor (Productivity Theory); Geogopalaus (Path Goal Theory) and Mac Gregery (Theory X and Y) are different motivational theories. But all of these theories explain the tangible motivation of employees. The Maslow's Needs Theory (1954) also point out the autonomous and competence in higher order needs of motivation. So this theory is closer to SDT in psychological perspective. The theory of Maslow's Hierarchy of Needs Theory (1954) explains the physiological, safety, social, self-esteem and self-actualization needs of a worker. This theory was divided in higher and lower level order. The physiological and safety needs explain lower level needs predominantly satisfied externally while the social, self-esteem and self-actualization are higher level needs are satisfied internally. So the first part of the theory explains the extrinsic motivation while the later one explains the intrinsic motivation. Reiss (2012) states two theories about motivation, Dualistic theory and multifaceted theory. The Dualistic theory explains two facets of motivation which are intrinsic motivation and extrinsic motivation, while the multifaceted theory explains genetically distinct motives of motivation. Many other motivation theories explain only intrinsic and extrinsic motivation in perquisite perceptive. The Maslow's Hierarchy of Needs Theory plays a prominent role of bridge for Self Determination Theory. The Self Determination Theory (SDT) not only explains the motivation (Intrinsic and Extrinsic) but also encourage for psychological satisfaction.

According to the theory of SDT by Ryan and Deci (2000), that people who are motivated intrinsically have the maximum level of self-determination and undertaking the behaviors for motives of significance and innate satisfaction. According to the study of Weinstein and Ryan (2011) that high level of self-determination reduces 
the harmful effects of stressors (work stress, job overload, performance pressure etc.).

According to the study of Eisenberger and Aselage (2008) that reward impacts on performance pressure and this depends on the alleged attainability of goal performance and this leads the way of task performing better. The study of Bartol and Durham (2000) states that incentive packages or plans are used to encourage or promote the superior performance, these inducements have been found as effective and positive on job performance and (Fay \& Thompson, 2001) this leads to positive job satisfaction, influence on creativity and influence on task interest. Eisenberger, Pierce, and Cameron (1999) explore and suggest that for superior performance the incentives or rewards increase the level of self-determination for greater intrinsic interest and creativity which leads to innovation and satisfaction. So on the basis of above two theories and literature the following hypothesis has been developed.

H4: Intrinsic/Extrinsic Motivation of Self Determination Theory (SDT) moderates the relation between work stress; job overload; performance pressure and job satisfaction.

\section{Methodology}

The banking sector was adopted for the data collection. The banking sector in Pakistan is very strong and rapidly growing sector. It has excellent contribution to the growth of economy of the country and has played an important role to minimize unemployment in the country. The total distribution of questionnaire was 120 and the collected data was 90 . So the response rate was 75 percent. The study was limited to banking sector only. The target population was assistant managers and supervisors. Descriptive analysis, hierarchical correlation and regression were used for measurement of variables.

\section{Measurement of Variables and Reliability Test}

For the measurement of work stress the "Occupational Stress Indicator" (OSI) was used and this was developed by Smith (1981) and then modified form was used by Cooper et al. (1988). This questionnaire is more modified form, containing eight (8) items having Cronbach's Alpha of 0.840. Job overload was measured by 10 items developed by Caplan et al. (1980) having alpha of 0.715 and range was 0.72 to 0.81 (Dwyer \& Ganster, 1991). Performance Pressure (PP) was measured by self-developed questions. The reason for this is non-availability of questionnaires or not researched extensively in management sciences. The questionnaire consist 6 questions. The internal consistency was measured as 0.815 in this study. Job satisfaction was measured by the "overall job satisfaction" questionnaire and was developed by Quinn and Shepard (1974) and modified form was used by Pond and Geyer (1991) explaining 6 items with 0.894 values of Cronbach's alpha. The extrinsic/intrinsic motivation was measured by a questionnaire developed by Tremblay et al. (2009) explains the intrinsic and extrinsic motivation (Self Determination Theory). The internal consistency for this study was 0.889 and the range was 0.87 and 0.72 . The Five Point Likert Scale was used for all the variables.

\section{Results}

\subsection{Correlation}

Table 1. Correlation among variables

\begin{tabular}{cccccc}
\hline Variables & 1 & 2 & 3 & 4 & 5 \\
\hline Work Stress & -- & & & & \\
Performance Pressure & $.416^{* *}$ & -- & & & \\
Job Overload & $.187^{*}$ & $.310^{* *}$ & -- & & \\
Job Satisfaction & $-.248^{* *}$ & $-.449^{* *}$ & $-.240^{* *}$ & -- & \\
Motivation & $-.303^{* *}$ & $-.147^{* *}$ & $-.240^{* *}$ & $.563 * *$ & -- \\
(Extrinsic and Intrinsic) & & & & & \\
\hline
\end{tabular}

Note. **. Correlation is significant at the 0.01 level (2-tailed).

Table 1 shows the direction of variables involved in the study. The relationship is positive significant $(0.416)$ between work stress and performance pressure. The shared variance between two variables is 17.30 percent $\left(.416^{2} * 100\right)$. The relationship between work stress and job overload is 0.187 . The relationship is positive and the shared variance between the variables is 3.5 percent. The relationship is negative $(-.248)$ between work stress and job satisfaction. The shared variance between variables is 6.2 percent. The relationship between work stress and extrinsic/intrinsic motivation is -.303 . The relationship between the two variables is negative. The shared variance between the variables is 9.18 percent. The correlation between performance pressure and job overload 
is 0.310 and this shows positive relationship between the variables. The shared variance between performance pressure and job overload is 9.61 percent. The relation with job satisfaction is -.449 and this explains the negative relationship. The shared variance between these two variables is 20.16 percent. The relation between performance pressure and motivation is negative (-.147). The shared variance between the variable is 2.17 percent. The relationship between job overload and job satisfaction is negative (-.240). The shared variance between them is 5.76 percent. The relationship between job overload and intrinsic and extrinsic motivation is -.240. The relationship is negative. The shared variance between them is 5.76 percent. At last the relation between job satisfaction and intrinsic and extrinsic motivation is 0.563 . The relationship is positive and shared variance between the variables is 31.70 percent.

\subsection{Hierarchical Multiple Regressions (Independent Variables)}

Table 2. Regression analysis among variables

\begin{tabular}{llllll}
\hline Variables & R & R2 & AdjR2 & F value & Sig \\
\hline $\begin{array}{l}\text { Work Stress } \\
\text { Job overload }\end{array}$ & 0.457 & 0.208 & 0.181 & 7.548 & 0.000 \\
Performance Pressure & & & & & \\
\hline
\end{tabular}

Note . Dependent Variable $=$ Job Satisfaction .

In the first step when the three independent variables (work stress, performance pressure and job overload) were added to the model. The researcher got the value of $R$ as 0.457 . It means that 45.7 percent contribution is being played by these three added variables in the model. The R square (R2) value is 0.208 . So it means that 20.8 percent of the variability in overall unit quality is being accounted for by work stress, performance pressure and job overload. The adjusted $\mathrm{R}$ square (AdjR2) value is 0.181 . This value takes into account the effect of the sample size and the number of predictors, that is the over rest amount of predictive capacity in the model based on sample size and the number of variables in the model. So there is adjustment made but not a big adjustment. The $\mathrm{F}$ value in the model summary is 7.548 and the ANOVA has the same value as above. So the model as a whole statically significant $(\mathrm{F}(3,86)=7.549, \mathrm{p}<.005)$.

Table 3. Regression analysis among variables

\begin{tabular}{|c|c|c|c|c|c|c|}
\hline Variables & $\mathrm{R}$ & $\mathrm{R} 2$ & R2change & AdjR2 & F change & Sig \\
\hline $\begin{array}{l}\text { Work Stress, } \\
\text { Job overload, } \\
\text { Performance Pressure, } \\
\text { WS, JoL, PP and (Moderator) }\end{array}$ & 0.457 & 0.208 & -- & 0.181 & 7.548 & 0.000 \\
\hline Intrinsic/Extrinsic Motivation & 0.689 & 0.475 & 0.267 & 0.450 & 19.228 & 0.000 \\
\hline
\end{tabular}

Note. Dependent Variable $=$ Job Satisfaction; WS= Work Stress; JoL= Job Overload; PP= Performance Pressure.

After moderating variable the value of $\mathrm{R}$ increased from 0.457 to 0.689 . So there is an increase about 0.232 $(23.3 \%)$. The R square (R2) value increased by 0.267 , this means that the variable intrinsic/extrinsic motivation explains an additional 0.267 (26.7 percent) of the variance in job satisfaction. The $\mathrm{F}$ change associated to the $\mathrm{R}$ square (R2 change) change of 0.267 (26.7 percent) is statistically significant. The ANOVA table explains that as a whole the model is significant $(.000)(\mathrm{F}(4,85)=19.228, \mathrm{p}<.005)$. 
Table 4. Coefficients

\begin{tabular}{|c|c|c|c|c|c|c|}
\hline \multirow[t]{2}{*}{ Model } & \multicolumn{2}{|c|}{ Unstandardized coefficient } & \multicolumn{3}{|c|}{ Standardized coefficient } & \multirow[t]{2}{*}{ Result } \\
\hline & $\mathrm{B}$ & std. Error & Beta & $\mathrm{t}$ & $\operatorname{sig}$ & \\
\hline \multicolumn{7}{|l|}{ Step1. } \\
\hline (Constant) & 4.516 & .736 & -- & 6.139 & 0.000 & \\
\hline WS & .097 & .122 & .085 & 0.793 & 0.430 & Supported \\
\hline PP & .461 & .117 & .415 & 3.926 & 0.001 & Supported \\
\hline $\mathrm{JoL}$ & .088 & .163 & .053 & 0.544 & 0.588 & Supported \\
\hline \multicolumn{7}{|l|}{ Step2. } \\
\hline (Constant) & 1.301 & .776 & -- & 1.676 & 0.097 & \\
\hline WS & 0.173 & .101 & .152 & 1.717 & 0.090 & Supported \\
\hline PP & 0.345 & .098 & .310 & 3.529 & 0.000 & Supported \\
\hline $\mathrm{JoL}$ & .144 & .134 & .087 & 1.082 & 0.283 & Supported \\
\hline IEM & 0.798 & .122 & .526 & 6.570 & 0.000 & \\
\hline
\end{tabular}

Note. WS $=$ Work stress; $\mathrm{PP}=$ Performance Pressure; $\mathrm{JoL}=\mathrm{Job}$ overload; $\mathrm{IEM}=$ Intrinsic/Extrinsic Motivation.

The model 1 shows significance level of each variable before adding the moderator variable. So as a whole the model is significant, but on each variable the significant variability is different. The work stress, performance pressure and job overload are the significant predictors. Table 4 provides the support for three hypotheses of this study. So this can state with 95 percent confidence that at less than 5 percent significance level; the work stress, performance pressure and job overload have positive effects on job satisfaction. The significance level of work stress increased to .090 , performance pressure level increased to significant level (.000) and job overload increased from 0.588 to 0.283 . So it shows that IEM (Intrinsic/Extrinsic Motivation) has the effect on all independent variables. So it clearly defines that motivation plays an important role to job satisfaction even the employees have stress, pressure and overload in work environment. In contrast the higher the absolute value of Beta; the more important is the variable in predicting the job satisfaction. In above table work stress (Beta $=.152)$, job overload $($ Beta $=.087)$ and the moderator variable $($ Beta $=.526)$ are the most important predictors to job satisfaction.

\section{Discussion of the Results}

The results support the direct and indirect relationship between work stress, performance pressure, job overload, job satisfaction and moderator variable intrinsic/extrinsic motivation of self-determination theory. The correlation between independent variables and job satisfaction was negative. The correlation between independent variables and moderator variable (intrinsic/extrinsic motivation) was also negative. The results of this study were supported by the studies conducted by different previous researchers (Bennett et al., 2001; Draper et al., 2003; Healy \& Mckay, 2000; Jain et al., 1996; Lu et al., 2007; Newbury \& Kamali, 2001). The relationship between job satisfaction and intrinsic/extrinsic motivation (moderator) was positive and significant. The previous studies of (Hackman \& Ollham, 1976; O'Brien, 1983) also support the positive and significant relationship between job satisfaction and motivation. In the regression analysis when work stress, performance pressure and job overload were added to the model of job satisfaction. The overall unit quality is being accounted as R2 .208 (20.8 percent) for the model by work stress, performance pressure and job overload and the contribution was (R) 0.457 (45.7 percent) by work stress, performance pressure and job overload to the job satisfaction. In second step when moderator variable "motivation" was added to the model of job satisfaction. The contribution of moderator was quiet effective to job satisfaction of employees. The contribution of motivation was .689 (68.9 percent) to the $(\mathrm{R}=.457)$ as increase was .232 ( 23.3 percent). The $\mathrm{R} 2$ change was .267. So this played a change of R2 of 0.208 to 0.475 . The whole model was statistically significant. In Table 4 the beta values of independent variables (WS beta $=.085$; P. Pressure $=.415$ and JO $=0.53$ ) by applying the moderator variable to the model, the beta value of work stress increased to (beta $=.152)$ and job overload increased to (beta $=.087)$ so on the basis of beta values it is significant contribution and the hypotheses $(\mathrm{H} 1$ and H2) are accepted while beta value of performance pressure decreased to (beta $=.310$ ) but according to Tabachnick and Fidell (2007) it could not be neglected the significance values of the relationship. The significance value increased to .000 . So it is also a predictor to the job satisfaction. The beta value of motivation was $($ Beta $=.526)$ and it is the highest beta value in the model. So motivation is the appropriate predictor to the model. So the hypothesis (H4) is accepted. 


\section{Suggestions, Limitations, and Future Research}

The banks should introduce the assistance programs to the employees in the situation when they deal with stress or uncertain situations. Employee empowerment and self-determination is important to control over work stress to enhance the job satisfaction level. The employees of the organizations should be trained for building job competencies and provide them job independency to do their job professionally. The improvement of self-determination of employees could be the best strategy for stress management. By this way employees will get higher motivation level and alternate result would be decrease of stress and pressure and it will maximize the level of job satisfaction.

This study was limited to the private sector's banks. The target population was assistant managers and supervisors in the region. The lower level of employees was not taken into consideration.

As this study was delimited to the private sector's banks in Pakistan, so the results of this study do not apply to the government sector's banks. The findings of this study may not be correct to other kind of organizations. So this study can be applied to other private or public and profitable or not profitable organizations.

\section{Conclusion}

This study will assist the managers of banking sectors in generating fit between work environment and job satisfaction. These factors are effective to encourage employees; that, how to release stress and increase the level of job satisfaction by using psychological satisfaction. Because global dynamics, work environment dynamics, customer focused dynamics, competitive environment strategies and changing technologies have created job overload, work pressure and job stressors in workplace of organizations. These kinds of stressors not only create fatigue or stress but also responsible for minimizing job satisfaction, poor performance, work overload, family conflict, work conflicts, destruction of creativity and physical and mental problems. Such kinds of issues are required to dissolve and create the environment of creativity, self-assessment, innovative, peaceful physical and mental climate, clear role information and inspirational atmosphere in workplace. The intrinsic/extrinsic motivational factors of SDT may be the adequate motivators for releasing stress level and maximizing level of job satisfaction. The intrinsic motivation, integrated regulation, identified regulation, interjected regulation, external regulation and amotivtion (Ryan \& Deci, 2000) have positively influence for minimizing stress level and maximizing job satisfaction. This study finds the most important point; that is to adopt the incentive or reward system for increasing the level of quantity, quality and the level of job satisfaction for minimizing different stress factors in organization besides the psychological satisfaction of employees. The self-determination theory is the most important aspect of motivation in workplace by personal fulfillment of employees. This is not only self-determination but also encourage workers with patience to work environment, job overload, work pressure and role stressors and high commitment and involvement with job and organization as well.

\section{References}

Ahsan, N., Abdullah, Z., Gun Fie, D. Y., \& Alam, S. S. (2009). A Study of Job Stress on Job Satisfaction among University Staff in Malaysia: Empirical Study. European Journal of Social Sciences, 8(1), 121-131.

Altaf, A., \& Awan, M. A. (2011). Moderating effect of workplace spirituality on the relationship of job overload and job satisfaction. Journal of Business Ethics, 104(1), 93-99. http://dx.doi.org/10.1007/s10551-011-0891-0

Argyle, M. (1989). Do happy workers work harder? The effect of job satisfaction on work performance. Netherland, Rotterdam: Universitaire Press.

Aryee, S., Srinivas, E. S., \& Tan, H. H. (2005). Rhythms of life: Antecedents and outcomes of work-family balance in employed parents. Journal of Applied Psychology, 90(1), 132-146. http://dx.doi.org/10.1037/0021-9010.90.1.132

Baltes, B. B., Briggs, T. E., Huff, J. W., Wright, J. A., \& Neuman, G. A. (1999). Flexible and compressed workweek schedules: A meta-analysis of their effects on work-related criteria. Journal of Applied Psychology, 84(4), 496-513. http://dx.doi.org/10.1037/0021-9010.84.4.496

Bartol, K. M., \& Durham, C. C. (2000). Incentives: Theory and practice. UK, Oxford: Blackwell.

Basset-Jones, N., \& Lloyd, G. C. (2005). Does Herzberg's Motivational Theory have staying power. Journal of Management Development, 24(10), 929-943. http://dx.doi.org/10.1108/02621710510627064

Beehr, T. A., \& Bhagat, R. S. (1985). Introduction to human stress and cognition in organizations. New York: John Wiley \& Sons. 
Ben, F., \& Payne, R. L. (1980). Stress and work: A review and theoretical framework, I. Personnel Review, 9(1), 19-29. http://dx.doi.org/10.1108/eb055400

Bennett, P., Lowe, R., Matthews, V., Dourali, M., \& Tattersall, A. (2001). Stress in nurses: Coping, managerial support, and work demand, Stress and Health. Journal of the International Society for the Investigation of Stress, 17(1), 55-63. http://dx.doi.org/10.1002/1532-2998(200101)17:1<55::AID-SMI879>3.0.CO;2-2

Blegen, M. A. (1993). Nurses' job satisfaction: A meta-analysis of related variables. Nursing Research, 42(1), 36-41.

Caplan, M. A., Cobb, S., French, J. R. P., Van Harrison, R., \& Pinneau, S. R. (1980). Job demands and worker health. Ann Arbor: University of Michigan, Institute for Social Research. Appendix E, pp. 238-239.

Cascio, W. F. (1995). Whither industrial and organizational psychology in a changing world of work. American Psychologist, 50(11), 928-939. http://dx.doi.org/10.1037/0003-066X.50.11.928

Cooper, C. L., Sloan, S. J., \& Williams, S. (1988). Occupational Stress Indicator Management Guide. UK, Windsor: NFER-Nelson Press.

Cummins, R. C. (1990). Job stress and the Buffering effect of supervisory support. Group and Organizational Studies, 15(1), 92-104. http://dx.doi.org/10.1177/105960119001500107

Deci, E. L., \& Ryan, R. M. (1985). Intrinsic motivation and self-determination in human behavior. New York: Plenum.

DeCharms, R. (1968). Personal causation: The internal affective determinants of behavior. Academic Press: New York.

Deci, E. L., \& Ryan, R. M. (2000). The "What" and "Why" of goal pursuits: Human needs and the self-determination of behavior. Psychological Inquiry, 11(4), 227-268. http://dx.doi.org/10.1207/S15327965PLI1104_01

Deci, E. L., \& Ryan, R. M. (2002). Handbook of self-determination research. New York, Rochester: University of Rochester Press.

Dormann, C., \& Zapf, D. (2002). Social stressors at work, irritation, and depressive symptoms: Accounting for unmeasured third variables in a multi-wave study. Journal of Occupational and Organizational Psychology, 75, 33-58. http://dx.doi.org/10.1348/096317902167630

Draper, J., Halliday, D., Jowett, S., Norman, I., Watson, R., Wilson-Barnett, J., ... O'Brien, K. (2003). NHS cadet schemes: Student experience, commitment, job satisfaction and job stress. Nurse Education Today, 24(3), 219-228. http://dx.doi.org/10.1016/j.nedt.2003.12.008

Dwyer, D. J., \& Ganster, D. C. (1991). The effects of job demands and control on employee attendance and satisfaction. Journal of Organizational Behavior, 12, 595-608. http://dx.doi.org/10.1002/job.4030120704

Eisenberger, R., \& Aselage, J. (2008). Incremental effects of reward on experienced performance pressure: Positive outcomes for intrinsic interest and creativity. Journal of Organizational Behavior, 30(1), 95-117. http://dx.doi.org/10.1002/job.543

Eisenberger, R., Pierce, W. D., \& Cameron, J. (1999). Effects of reward on intrinsic motivation: Negative, $\begin{array}{lllll}\text { neutral, and } & \text { positive. Psychological }\end{array}$ http://dx.doi.org/10.1037/0033-2909.125.6.677

Elangovan, A. R. (2001). Causal ordering of stress, satisfaction and commitment, and intention to quit: A structural equations analysis. Leadership and Organization Development Journal, 22(4), 159-165. http://dx.doi.org/10.1108/01437730110395051

Ettner, S. L., \& Grzywacz, J. G. (2001). Worker's perceptions of how jobs affect health: A socialecological perspective. Journal of Occupational Health Psychology, 6(2), 101-113. http://dx.doi.org/10.1037//1076-8998.6.2.101

Fay, C. H., \& Thompson, M. A. (2001). Contextual determinants of reward systems' success: An exploratory study. Human Resources Management, 40(3), 213-226. http://dx.doi.org/10.1002/hrm.1012

Fields, D. L. (2002). Taking the measure of work; A guide to validated scales for organizational research and diagnosis. SAGE Publication, Thousand Oaks: Inc.

Gardner, D. G., \& Cummings, L. L. (1988). Activation theory and task design: Review and reconceptualization', In B. M. Staw, and L. L. Cummings, (Eds.), Research in Organizational Behavior (Vol. 10, pp. 81-122). 
Greenwich, CT: JAI Press Inc,.

Grover, S. L., \& Crooker, K. J. (1995). Who appreciates family responsive human resource policies: The impact of family friendly policies on the organizational attachment of parents and non-parents. Personnel Psychology, 48(2), 271-288. http://dx.doi.org/10.1111/j.1744-6570.1995.tb01757.x

Hagger, M. S., Chatzisarantis, N. L. D., \& Biddle, S. J. H. (2002). The influence of autonomous and controlling motives on physical activity intentions within the theory of planned behavior. British Journal of Health Psychology, 7(3), 283-297. http://dx.doi.org/10.1348/135910702760213689

Hackman, R. J., \& Oldham, G. R. (1976). Motivation through the design of work: Test of a theory. Organizational Behavior and Human Decision Process, 16, 250-279. http://dx.doi.org/10.1016/0030-5073(76)90016-7

Hackman, J. R., \& Oldham, G. R. (1975). Development of the job diagnostic survey. Journal of Applied Psychology, 60(2), 159-170. http://dx.doi.org/10.1037/h0076546

Healy, C. M., \& McKay, M. F. (2000). Nursing stress: The effects of coping strategies and job satisfaction in a sample of Australian. Journal of Advanced Nursing, 31(3), 681-688. http://dx.doi.org/10.1046/j.1365-2648.2000.01323.x

Jain, V. K., Lall, R., McLaughlin, D. G., \& Johnson, W. B. (1996). Effect of locus of control, occupational stress, and psychological distress on job satisfaction among nurses. Psychological Reports, 78(3), 1256-1258. http://dx.doi.org/10.2466/pr0.1996.78.3c.1256

Jex, S. M., \& Beehr, T. A. (1991). Emerging theoretical and methodological issues in the study of work related stress. Research in Personnel and Human Resources Management, 9(31), 1-365.

Kahn, R. (1980). Conflict, ambiguity, and overload: Three elements in job stress. In D. Katz, R. Kahn, \& J. Adams, (Eds.), The study of organizations (pp. 418-428). San Francisco, CA: Jossey-Bass.

Kawakami, N., Kobayashi, Y., Takao, S., \& Tsutsumi, A. (2005). Effects of web based supervisor training on supervisor support and psychological distress among workers: A randomized controlled trial. Preventive Medicine, 41(2), 471-478. http://dx.doi.org/10.1016/j.ypmed.2005.01.001

Landsbergis, P. A. (1988). Occupational stress among health care workers: A test of the job demands control model. Journal of Organizational Behavior, 9(3), 217-239. http://dx.doi.org/10.1002/job.4030090303

Lum, L., Kervin, J., Clark, K., Reid, F., \& Sirola, W. (1998). Explaining nursing turnover intent, job satisfaction, pay satisfaction or organizational commitment. Journal of Organizational Behavior, 19(3), 305-320. http://dx.doi.org/10.1002/(SICI)1099-1379(199805)19:3<305::AID-JOB843>3.0.CO;2-N

Maslow, A. (1954). Motivation and Personality. New York: McGraw-Hill.

McVicar, A. (2003). Workplace stress in nursing: A literature review. Journal of Advanced Nursing, 44(6), 633-642. http://dx.doi.org/10.1046/j.0309-2402.2003.02853.x

Newbury, B. D., \& Kamali, F. (2001). Psychological stress, anxiety, depression, job satisfaction, and personality characteristics in pre-registration house officers. Postgraduate Medical Journal, 77(904), 109-111. http://dx.doi.org/10.1136/pmj.77.904.109

Nirel, N., Goldwag, R., Feigenberg, Z., Abadi, D., \& Halpern, P. (2008). Stress, work overload, burnout, and satisfaction among paramedics in Israel. Prehospital and Disaster Medecine, 23(6), 537-546. http://dx.doi.org/10.1017/S1049023X00006385

Nordqvist, S., Hovmark, S., \& Zika-Viktorsson, A. (2004). Perceived time pressure and social processes in project teams. International Journal of Project Management, 22(6), 463-468. http://dx.doi.org/10.1016/j.ijproman.2003.11.005

O'Brien, G. E. (1983). Skill-utilization, skill-variety and the job characteristics model. Australian Journal of Psychology, 35(3), 455-460. http://dx.doi.org/10.1080/00049538308258757

Pond, S. B., \& Geyer, P. D. (1991). Differences in the relation between job satisfaction and perceived work alternatives among older and younger blue-collar workers. Journal of Vocational Behavior, 39(2), 251-262. http://dx.doi.org/10.1016/0001-8791(91)90012-B

Quinn, R. P., \& Shepard, L. G. (1974). The 1972-1973 Quality of Employment Survey. Ann Arbor: University of Michigan, Institute for Social Research.

Qureshi, I., Jamil, R. A., Iftikhar, M., Arif, S., Lodhi, S., Naseem, I., \& Zaman, K. (2012). Job Stress, Workload, 
Environment and Employees Turnover Intention: Destiny or Choice. Archives Des Sciences, 65(8), 230-240.

Reiss, S. (2012). Intrinsic and Extrinsic Motivation: Sage. London: Olivers Yard, Publications Ltd, 1.

Ryan, R. M., \& Deci, E. L. (2000). Self-determination theory and the facilitation of intrinsic motivation, social development, and well-being. American Psychologist, 55(1), 68-78. http://dx.doi.org/10.1037/0003-066X.55.1.68

Ryan, R. M., \& Deci, E. L. (2000). Intrinsic and extrinsic motivations: Classic definitions and new directions. Contemporary Educational Psychology, 25(1), 54-67. http://dx.doi.org/10.1006/ceps.1999.1020

Sheldon, K. M., Ryan, R. M., Deci, E. L., \& Kasser, T. (2004). The independent effects of goal contents and motives on well-being: It's both what you pursue and why you pursue it. Personality and Social Psychology Bulletin, 30(4), 475-486. http://dx.doi.org/10.1177/0146167203261883

Smith, R. M. (1981). Person fit analysis with the Rasch model. Chicago: University of Chicago Press.

Spector, P. E., \& Jex, S. M. (1998). Development of four self-report measures of job stressors and strain: Interpersonal conflict at work scale, organizational constraints scale, quantitative workload inventory and physical symptoms inventory. Journal of Occupational Health Psychology, 3(4), 356-367.

Stamps, P. L., \& Piedmonte, E. B. (1986). Nurses and work satisfaction: An index for measurement. Ann Arbor, MI: Health Administration Press Perspectives.

Sveinsdottir, H., \& Biering, P., \& Ramel, R. (2005). Occupational stress, job satisfaction and working environment among Icelandic nurses: A cross sectional questionnaire survey. International Journal of Nursing Studies, 43(7), 875-889. http://dx.doi.org/10.1016/j.ijnurstu.2005.11.002

Tabachnick, B. G., \& Fidell, L. S. (2007). Using multivariate statistics (5th), Boston, Pearson Education,.

Townley, G. (2000). Long hours culture causing economy to suffer. Management Accounting, 78(6), 3-5.

Tremblay, M. A., Blanchard, C. M., Taylor, S., Pelletier, L. G., \& Villeneuve, M. (2009). Work Extrinsic and Intrinsic Motivation Scale: Its value for organizational psychology research. Canadian Journal of Behavioural Science, 41(4), 213-226. http://dx.doi.org/10.1037/a0015167

Vinokur-Kaplan, J. X. (1991). Job Satisfaction among Social Workers in Public and Voluntary Child Welfare Agencies. Child Welfare, 70(1), 81-91.

Weinstein, N., \& Ryan, R. M. (2011). A self-determination theory approach to understanding stress incursion and responses. Stress and Health, 27(1), 4-17. http://dx.doi.org/10.1002/smi.1368

Yun, L. K., Chih, C., L., \& Lan, W. H. (2007). Relationships between Professional commitment, Job satisfaction, and work stress, in public health nurses in Taiwan. Journal of Professional Nursing, 23(2), 110-116. http://dx.doi.org/10.1016/j.profnurs.2006.06.005

\section{Copyrights}

Copyright for this article is retained by the author(s), with first publication rights granted to the journal.

This is an open-access article distributed under the terms and conditions of the Creative Commons Attribution license (http://creativecommons.org/licenses/by/3.0/). 